\title{
Non-technical innovation and entrepreneurship in project-based small service firms
}

\begin{tabular}{|c|c|}
\hline $\begin{array}{l}\text { Authors: } \\
\text { Chen Wang } \\
\text { Yee Lin Lee } \\
\text { Jeffrey Boon } \\
\text { Lincoln C. Wo } \\
\text { Hamzah Abdu }\end{array}$ & $\begin{array}{l}\text { lui Yap }{ }^{3} \text { (D) } \\
d^{4} \text { (D) } \\
\text {-Rahman }\end{array}$ \\
\hline $\begin{array}{l}\text { Affiliations: } \\
{ }^{1} \text { Department } \\
\text { Management, } \\
\text { University, Xia }\end{array}$ & $\begin{array}{l}\text { f Construction } \\
\text { Huaqiao } \\
\text { men, China }\end{array}$ \\
\hline $\begin{array}{l}{ }^{2} \text { Faculty of Bu } \\
\text { University of } \\
\text { Lumpur, Mala }\end{array}$ & $\begin{array}{l}\text { It Environment, } \\
\text { Malaya, Kuala } \\
\text { ysia }\end{array}$ \\
\hline $\begin{array}{l}{ }^{3} \text { Department } \\
\text { Lee Kong Chia } \\
\text { Engineering a } \\
\text { Universiti Tun } \\
\text { Rahman (UTA } \\
\text { Jaya, Malaysia }\end{array}$ & $\begin{array}{l}\text { f Surveying, } \\
\text { Faculty of } \\
\text { d Science, } \\
\text { a Abdul } \\
\text { ), Petaling }\end{array}$ \\
\hline $\begin{array}{l}{ }^{4} \text { Department } \\
\text { Management, } \\
\text { Otago, Duned }\end{array}$ & $\begin{array}{l}\text { f Business and } \\
\text { University of } \\
\text { n, New Zealand }\end{array}$ \\
\hline $\begin{array}{l}\text { Correspondin } \\
\text { Chen Wang, } \\
\text { derekisleon@ }\end{array}$ & $\begin{array}{l}\text { Sauthor: } \\
\text { smail.com }\end{array}$ \\
\hline $\begin{array}{l}\text { Dates: } \\
\text { Received: } 18 \\
\text { Accepted: } 29 \\
\text { Published: } 27\end{array}$ & $\begin{array}{l}\text { ec. } 2019 \\
\text { May } 2020 \\
\text { Aug. } 2020\end{array}$ \\
\hline $\begin{array}{l}\text { How to cite th } \\
\text { Wang, C., Lee, } \\
\text { Yap, J.B.H., Wc } \\
\text { Abdul-Rahmar } \\
\text { 'Non-technica } \\
\text { and entrepren } \\
\text { project-based } \\
\text { firms', South A } \\
\text { Journal of Eco } \\
\text { Management } \\
\text { a3498. https:/ } \\
\text { 4102/sajems.V }\end{array}$ & $\begin{array}{l}\text { is article: } \\
\text { Y.L., } \\
\text { od, L.C. \& } \\
\text {, H., 2020, } \\
\text { innovation } \\
\text { eurship in } \\
\text { small service } \\
\text { frican } \\
\text { homic and } \\
\text { Sciences 23(1), } \\
\text { /doi.org/10. } \\
\text { 23i1.3498 }\end{array}$ \\
\hline Read online: & \\
\hline 回触回 & $\begin{array}{l}\text { Scan this QR } \\
\text { code with your } \\
\text { smart phone or } \\
\text { mobile device } \\
\text { to read online. }\end{array}$ \\
\hline
\end{tabular}

Background: Because of doubts about the sufficiency of convention indicators to continually gauge innovative outcomes at the firm level, a burgeoning stream of scholars has shifted their empirical efforts to the theoretical development of non-technical innovations.

Aim: This study investigates the contribution of non-technical, innovative, entrepreneurial and marketing endeavours to the development of superior entrepreneurship through two types of firm capabilities.

Setting: Over several stages, a structured questionnaire form was formulated. Firstly, an extensive review of previous similar research was performed to identify the adoptable scale items. After adjusting the scales based on the feedback from the pre-testers, the final questionnaire comprised 55 items measured on a five-point Likert-type scale.

Methods: A total of 155 valid questionnaires, with the inclusion of late-responses, were obtained and this represented a response rate of $22 \%$. Particularly, a conceptual model connecting market orientation, organisational learning, non-technical innovation and entrepreneurship was tested using partial least square path modelling.

Results: In considering the criticality of innovation as the fulcrum of service-based delivery, our model advances the existing empirical approaches with a more intangible dimensionality of innovative efforts. Overall, the model distinguishes that small service firms engaging in dual modes of non-technical innovation strategically nurture intangible capabilities, which in turn provides them with enduring performance outcomes in outperforming competitors.

Conclusion: The findings could assist small firms in accomplishing new value creation via non-technical innovations.

Keywords: entrepreneurship; non-technological innovation; organisational learning; innovation; small-sized firms; SME.

\section{Introduction}

For many years, research on innovation has tended to endorse a technical-centred advancement (Davies, Manning \& Söderlund 2018; Drejer 2004; Slaughter 2000). Due to doubts about the sufficiency of these convention indicators to continually gauge the innovative outcomes at the firm level, a burgeoning stream of scholars has shifted their empirical efforts to the theoretical developing of non-technical innovations (Armbruster et al. 2006; Camison \& Villar-Lopez 2014; Caroli \& Van Reenen 2001; Evangelista \& Vezzani 2010; Gallego \& Rubalcaba 2012; Greenan 2003; Hamel 2006; Mol \& Birkinshaw 2009; Naidoo 2010; OECD 2005; Shergill \& Nargundkar 2005). These findings reported that non-technical innovation, which suggests advantage within organisational or managerial and marketing innovations, can harness the extant research stream with an enhanced understanding of the innovative dynamism and the performance consequences of engagement (Iliescu \& Ciocan 2017; Martínez-Román, Tamayo \& Gamero 2017; Nyström, Nilsson \& Lind 2016). The inclusion of non-technical metrics is anecdotally meritorious in terms of their complementing role in new technical deliveries (Aravind, Damanpour \& Devece 2014; Evangelista \& Vezzani 2010; Gallego \& Rubalcaba 2012; Weerawardena, O'Cass \& Julian 2006). In spite of the myriad arguments, the question of how non-technical innovation fundamentally pullulates in its own right remains tangential in discussion (Turk 2016; Xue et al. 2018).

This study extends the previous line of reasoning on three fronts. Firstly, centred on the nontechnical innovation, Camison and Villar-Lopez (2011) encourage research on its capabilitiesbased antecedents and performance consequences. To date, reports identifying the effects of firm capabilities, such as market-oriented competence (Baker \& Sinkula 1999; Im \& Workman 2004; Salavou 2002; Zhang \& Duan 2010) and learning capacity (Alegre \& Chiva 2008; Pesamaa et al.

Copyright: (C) 2020. The Authors. Licensee: AOSIS. This work is licensed under the Creative Commons Attribution License. 
2013), were subject to fragmentation as seen in the biased preference towards technical innovative offerings. Although the central importance of market-oriented and learningbased capabilities has been long attested in the literature, understanding of theirintegrativeimpactonentrepreneurship, first directly and second via the mediated effect of nontechnical innovation, is as yet nearly non-existent. This issue is especially crucial given that non-technical innovative activities are essential sources of superior entrepreneurship (Mol \& Birkinshaw 2009; Naidoo 2010; Shergill \& Nargundkar 2005). Extending the original reasoning, the present study moulds the antecedents and consequence of organisational and marketing innovations together in a single model.

Secondly, beyond the ubiquitous manufacturing orthodoxies (Camison \& Villar-Lopez 2011, 2014; Weerawardena 2003), this study explicates the empirical value of a service-centred approach in analysing non-technical innovation. Innovation modes are relatively heterogeneous; in fact, there is considerable variation between firms with product-centric market settings and those engaging with service-based value creation (Kindstrom, Kowalkowski \& Sandberg 2013). In this respect, service firms that based their business deliveries upon projects have been identified as ideal for the conceptualisation of service-based innovation (Salunke, Weerawardena \& McColl-Kennedy 2011). Given their distinct features, such as co-creation of outputs around one-off projects, temporary coalition with varying business actors and business deliveries within complex in-situ sites (Manley 2008), project-based service firms reflect characteristics differentially unique to the services regime. In the projectbased context, this study addresses the need for greater evidence in conceptualising innovation within the services setting (Hauser, Tellis \& Griffin 2006; O'Cass et al. 2013).

Thirdly, the growing literature on non-technical innovation pays scant attention to the implications for small firms as compared to larger organisations (Pereira \& Romero 2013; Turk 2016; Xue et al. 2018; Zubizarreta et al. 2017). This is detrimental for small businesses, for they do not always engage in value-creating changes via research and development (Acs \& Audretsch 1988). Despite the innate scarcity of resources, small firms have demonstrated an innovation pattern conceivably different from that of their larger counterparts (Gallego \& Rubalcaba 2012). This study attempts to capture the essence of non-technical measures in connection with resource-poor firms.

Aware of the aforementioned inconsistencies, this study conjectures that innovative firms would purposefully develop certain capabilities for which superior performance have been found. Theorising non-technical innovation as the likely mediator, a conceptual framework is formulated to distinguishing the interplay effect of market orientation (MO) and organisational learning (OL) on entrepreneurship within a sample of small Malaysian contracting service firms. The article starts with a review of related literature and a description of the conceptual framework with its hypotheses. The design of the study with empirical analysis from 155 project-based small innovative firms is then presented.

\section{Market orientation and non-technical innovation}

Market orientation has long been addressed as a central tenet of organisational strategy that rests profit maximisation on the continuous deciphering of volatile market demands (Fernandez, Roy \& Chiambaretto 2018; Lettice, Tschida \& Forstenlechner 2014). As part of the cornerstone of organisation culture (Narver \& Slater 1990), MO leads to specific behavioural traits that translate into organisational competitive performance (Han, Kim \& Srivastava 1998; Matear et al. 2002). Facing rapidly changing consumer preferences, the proficiency to integrate a market-oriented attitude with innovation focus would furnish small businesses with superior service advantages (Iliescu \& Ciocan 2017; Raju, Lonial \& Crum 2011; Salavou 2002; Turk 2016). Even in times of economic crisis, firms with a stronger market focus indicate a greater ability to withstand adverse turbulence than those exhibiting a weaker market focus (Lettice et al. 2014).

In an empirical sense, the MO scales have gained prominent validation in services-specific contexts, such as hotel services (Sin et al. 2005), software services (Akman \& Cengiz 2008), chartered surveying services (Tay \& Morgan 2002) and food services (Dibrell, Craig \& Hansen 2011). Alternatively, the scholarly efforts view $\mathrm{MO}$ as a long established threedimensional construct that includes customer orientation, competitor orientation and inter-functional coordination (Narver \& Slater 1990) or intelligence generation, intelligence dissemination and organisation-wide responsiveness (Kohli \& Jaworski 1990). Despite some variation around the alternate use or adoption of the two frameworks, it is worth noting that MO is an important contributor to long-term business performance throughout the services domain (Lettice et al. 2014; Matear et al. 2002; Sin et al. 2005; Tay \& Morgan 2002; Tsiotsou 2010).

Building on prior studies, this study infers that $\mathrm{MO}$ is particularly relevant to project-based business provisioning (Martínez-Román et al. 2017; Nyström et al. 2016). In essence, firms with close connections with customers, clients and value chain partners of diverse functions and professions are endowed with a higher relationship-building competency to better respond to site-based uncertainties in relation to successful outcomes of innovative project deliveries (Manley 2008; Preeker \& Giovanni 2018). Also, project-based firms are inherently competitor-oriented in their strategic establishment of pricing and bidding strategies for winning project tenders (Coskun, Erdis \& Demirci 2013). Where the propensity towards MO is generally stronger in small firms in contrast with larger firms (Pelham 1999; Raju et al. 2011), this study makes a clear analysis of the role of market-oriented posture in complementing a business's project-based nature:

H1: Market orientation is positively related to entrepreneurship

\section{Market orientation and organisational learning}

$\mathrm{MO}$, however, evolves as a function of organisational core competency only when it is amalgamated with a learning climate (Slater \& Narver 1995). Proposed as antecedent of 
$\mathrm{MO}$, organisational learning, in its basic sense, refers to (Jerez-Gómez, Cespedes-Lorente \& Valle-Cabrera 2005):

\begin{abstract}
... the capability of an organization to process knowledge - in other words, to create, acquire, transfer and integrate knowledge - and to modify its behaviour to reflect new cognitive situations with a view to improving its performance. (p. 716)
\end{abstract}

Such learning norms strengthen market-driven firms with a better sensing of new information in the marketplace (Sinkula 1994; Slater \& Narver 1995) and being more flexible and responsive in value creation than the competitors (Day 1994). Put differently, a high degree of learning within an organisation constitutes critical sources for long-term superior performance (Alegre \& Chiva 2008; Baker \& Sinkula 1999; Hurley \& Hult 1998; Jimenez-Jimenez \& Sanz-Valle 2011). Any organisation, overtly, might eventually end with dysfunction without the relentless pursuit of learning (DiBella 1995).

Mere aspiration to transform into a learning organisation is inadequate and, additionally, firms must attempt to turn their learning into capabilities (Hamel \& Prahalad 1994): 'creating a market orientation is only a start' (Slater \& Narver 1995:63). Inspired by these implicative assertions, various scholars have exposed that much of the firm's competitive capability hinges on the managerial coordination to realise the synergistic effect of MO and organisational learning to result in the aforementioned capability (Baker \& Sinkula 1999; Farrell \& Oczkowski 2002; Hult, Hurley \& Knight 2004; Hurley \& Hult 1998; Keskin 2006; Lertpachin, Wingwon \& Noithonglek 2013; Sinkula 1994; Sinkula, Baker \& Noordeweir 1997). Echoing the importance of the combinative view, however, the prior findings did not examine in particular whether specific antecedents, such as organisational learning, would nurture small firms' market-oriented competence across their routine business activities (Raju et al. 2011). Addressing this need, it is postulated that:

$\mathbf{H 2}$ : Organisational learning is positively related to entrepreneurship.

H3: Market orientation is positively related to organisational learning.

\section{Non-technical innovation}

In evaluating the preceding research, it is uncovered that innovation mostly goes along with the aim of achieving some sort of competitive advantage to outperforms rivals (Salunke et al. 2011). While the conventional conceptualisation of innovation dominates over product or production means (Drejer 2004; Slaughter 2000), such a tangible approach has increasingly attracted criticism for the risk of disintegrating other relevant metrics (Xue et al. 2018). Joining this debate, recent scholarly efforts reform the dynamism of innovation in the role of non-technical innovation (Brochner 2010; Hipp \& Grupp 2005; OECD 2005) that is suggested as one of the pivotal pillars of organisational competitiveness (Evangelista \& Vezzani 2010; Greenan 2003; Mol \& Birkinshaw 2009). Tracked through the extant literature, theoretically and empirically, non-technical advancements are depicted to entail organisational (or managerial) and marketing innovations (Camison \& Villar-Lopez 2011; OECD 2005).
Structurally, organisational innovation includes changes in responsibilities or the information flow and divisional structure of a firm; procedurally, organisational innovation involves the new implemented routines, processes and operations within firm (Armbruster et al. 2006). In project business, new business practices would enable firms to acquire a greater competitive advantage (Seaden et al. 2003), and enhance problem-solving and profitability (Pellicer et al. 2012). Firms pursuing advanced practices in management could better manage projects over a range of related activities, resources and business linkages (Hakansson \& Ingemansson 2013). Marketing innovation, on the other hand, relates to new marketing methods that manifest significant changes in design or packaging, placement, promotion and pricing (OECD 2005). From a practical standpoint, innovative marketing efforts are especially important for project-based companies in aiding business development (Dikmen, Birgonul \& Ozcenk 2005). A recent study has also demonstrated that construction organisations that carefully and systematically integrated their pricing and promotion strategies with their firm's specific resources had a higher chance of successful tender bidding (Coskun et al. 2013).

To sum up, both organisational and marketing innovations have a substantial impact on business success. Potentially, non-technical innovation produces similar beneficial effects as those depicted in cost-reducing process enhancements or customer value-generating product developments (Evangelista \& Vezzani 2010). To date, how non-technical measures enable firms of a project-based nature to seize greater market positional advantage is underexplored (Brochner 2010). Using a small firm as the focal point, this study accordingly advances an analysis of non-technical innovation to appropriately capture its impact on businesses that focus on project-based provisioning.

\section{Market orientation and non-technical innovation}

Innovation is essentially an outcome of strong marketoriented culture (Hurley \& Hult 1998). Underlined as one of the 'core-value creating capabilities' (Slater \& Narver 1994), $\mathrm{MO}$ enables access to valuable inputs required for innovation such as accumulated knowledge from customers, rivals and technologies (Deshpande, Farley \& Webster 1993). In this connection, innovative decision-makers rely on customer input to secure improved outcomes through the strategic alignment of customer-oriented needs with organisational innovation efforts (Alam 2002). Not only does marketoriented culture foster an optimal environment for continuous value creation (Han et al. 1998), it also allows firms to capitalise on market-based success through customising the benefits of novel offerings for customers (Baker \& Sinkula 1999; Matear et al. 2002; Tsiotsou 2010). Accordingly, knowledge sources relating to clients or competitors can essentially inspire new organisational practices (Birkinshaw \& Mol 2006). To better accommodate customer needs, both intra-organisational and inter-organisational innovation could support firms with greater efficiency, effectiveness and flexibility in their service deliveries (Armbruster et al. 2006). Therefore, the present study conjectures that firms integrate 
both marketing and organisational innovation into their quest to better accommodate market demands:

H4: Market orientation is positively related to organisational innovation.

H5: Market orientation is positively related to marketing innovation.

\section{Organisational learning and non-technical innovation}

Literature has long acknowledged the role of knowledgebased capabilities in driving the discovery of value-creating opportunities in the form of innovation (Alegre \& Chiva 2008; Hurley \& Hult 1998; Jimenez-Jimenez \& Sanz-Valle 2011; Pesamaa et al. 2013). Nonetheless, rarely are these recognised in the domain of non-technical innovation (Nyström et al. 2016; Zubizarreta et al. 2017). Exceptionally, a recent empirical analysis conducted on industrial firms views both organisational memory and learning capabilities as the key to discover novel organisational and marketing practices (Camison \& Villar-Lopez 2011). Likewise, some studies suggest that different forms of learning, such as marketfocused, internally focused and relationally focused learning, exert different impacts on the development of innovative managerial practices and marketing instruments (Weerawardena 2003; Weerawardena et al. 2006). Even in high-tech industries, new aspects of organisational practice are essential in nurturing an optimum learning culture that fosters firms' competitiveness (Lee, Tan \& Chiu 2008). These empirical investigations were in consensus about the value derived from both organisational learning and non-technical advancement to achieve positive organisational outcomes (Camison \& Villar-Lopez 2011; Lee et al. 2008; Weerawardena 2003; Weerawardena et al. 2006).

In relation to innovation, the importance of learning has also been discussed in project-based business literature (Drejer \& Vinding 2006; Gann \& Salter 2000; Salunke et al. 2011). Along with the impedance of knowledge loss between various firms associated with boundary-crossing projects, Gann and Salter (2000) suggest that firms fail to coherently integrate their onoff project experience into the repetitive business routine to achieve sustained innovative opportunities. Also, Drejer and Vinding (2006) accentuate that innovative initiatives are anchored through firms' continuous efforts to collect, diffuse and assimilate project-specific knowledge at the firm level. Interestingly, Manley (2008) argues that the known liabilities of smallness could turn into positive features of small firms, where the knowledge transposal processes are relatively easier and therefore promote the generation of new ideas despite the resource-poor environment. In multiple case studies, Salunke et al. (2011) decipher the dynamic mode of different learning activities in connection with the occurrence of project-oriented innovation. However, it is important to note that these studies are exclusive to the conceptualisation of innovation over non-technical means. Given that projectbased firms innovate technically and non-technically (Brochner 2010), the likely impact of organisational learning on non-technical measures is posited as follows:
H6: Organisational learning is positively related to organisational innovation.

H7: Organisational learning is positively related to marketing innovation.

\section{Non-technical innovation and entrepreneurship}

The extant research offering evidence of the practical relevance of non-technical innovation in regard to entrepreneurship is inconclusive. While some researchers echo the strong positive impact that non-technical innovation has on performance (Caroli \& Van Reenen 2001; Evangelista \& Vezzani 2010; Greenan 2003; Hamel 2006; Mazzanti, Pini \& Tortia 2006; Mol \& Birkinshaw 2009; Shergill \& Nargundkar 2005), others present contradictory conclusions to the empirical relationship (Cappelli \& Neumark 2001; Staw \& Epstein 2000; Walker, Damanpour \& Devece 2010). Furthermore, the incongruous findings are complicated by varying metrics of organisational outcomes, such as brand performance (Weerawardena et al. 2006), improvement in future productivity (Mol \& Birkinshaw 2009), reputational advantage (Staw \& Epstein 2000), organisational effectiveness (Jimenez-Jimenez \& SanzValle 2011) and others. Positing non-technical innovation as a predictor of positive entrepreneurship, which has been argued to be better measured from both financial and market perspectives (Cheng \& Krumwiede 2012; Matear et al. 2002; Shergill \& Nargundkar 2005), the present study proposed the following hypotheses:

H8: The greater the organisational innovation, the greater the entrepreneurship.

H9: The greater the marketing innovation, the greater the entrepreneurship.

The research framework of this study is presented in Figure 1.

\section{Research methods and procedures}

Over several stages, a structured questionnaire was formulated. Firstly, an extensive review of previous similar research was performed to identify the adoptable scale items. These items were pre-tested using a sample of 30 senior managers with working experience in small project-based service firms. After adjusting the scales based on the feedback from the pre-testers, the final questionnaire comprised 55 items measured on a fivepoint Likert-type scale. An initial sample was then assembled from key construction firms listed in the Malaysian Smalland-Medium-Enterprises Corporation and the Malaysian

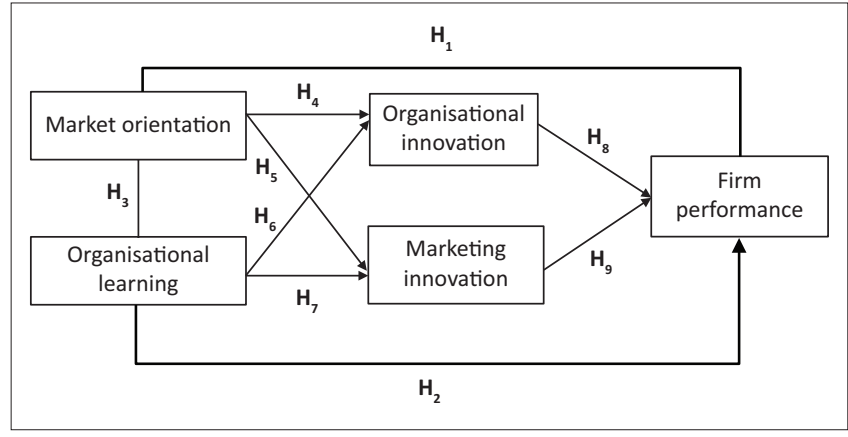

FIGURE 1: Research framework. 
Construction Industry Development Board listings. Following Spanos and Lioukas (2001), the sampling frame was refined by firms having 10-49 full-time employees (i.e. small firms) and a final sample of 700 firms was yielded. As it has been corroborated that members of the executive level in a firm (e.g. owner, managing director, CEO) are the 'single most knowledgeable and valid information sources' (Lechner, Dowling \& Welpe 2006:525), these people were selected as the key informants. After three weeks from the first wave of primary distribution, reminder letters were sent out to the non-response firms. A total of 155 valid questionnaires, with the inclusion of late responses, were obtained and this represented a response rate of $22 \%$. The sample varied between firms that based business upon main contracting (56\%) and specialist contracting (43\%) projects delivery. On average, firms were aged around 15 years old and the respondents attributed to the firms had approximately 8 years of business experience. In terms of market size, the vast majority (95\%) of the firms operate in domestic markets whereas a small minority $(5 \%)$ operate overseas. To assess the potential presence of non-response bias (Armstrong \& Overton 1977), the early and late responding groups were compared in terms of the mean of all variables. The t-test methodology detected no systematic differences between the two groups.

All measures used in the current research were drawn from previously similar studies.

\section{Market orientation}

This study follows Nasution and Mavondo's (2008) work to operationalise $\mathrm{MO}$ as four dimensions: customer orientation, competitor orientation, inter-functional coordination and latent need fulfilment. The additional dimension of latent need fulfilment is a crucial focus on customers' unexpressed needs in order to discern and anticipate potential marketbased opportunities by proactive means. In consideration of previous works (Day 1994; Slater \& Narver 1995) that omitted the component of inter-functional coordination, the final MO scale consists of customer orientation (4 items), competitor orientation (4 items) and latent need fulfilment (4 items), structured on a five-point Likert-type scale (anchored by 'strongly disagree' and 'strongly agree').

\section{Organisational learning}

This study adopts the scale developed by Jerez-Gómez et al. (2005) in interpreting the observed OL across four dimensions: managerial commitment (5 items), systems perspective (3 items), openness and experimentation (4 items) and knowledge transfer (4 items). Like MO, OL is assessed using a five-point Likert-type scale (anchored by 'strongly disagree' and 'strongly agree').

\section{Non-technical innovation}

This study adapted the scales previously developed by Dikmen et al. (2005) and OECD (2005). Two dimensions, organisational innovation (4 items) and marketing innovation
(4 items), were self-assessed by respondents on a five-point Likert-type scale (anchored by 'never practice' and 'always practice'). All eight items are self-reported by respondents to conquer the difficulties in requesting sensitive information pertaining to organisations (Im \& Workman 2004). Finally, age of the firm was viewed as the extraneous variable given its documented effect on innovation-related performances (Jimenez-Jimenez \& Sanz-Valle 2011; Sinkula 1994).

\section{Data interpretation and results}

A combination of SPSS 22 and Smart-PLS 2.0 software packages were used for data visualisation.

\section{Validation of measures}

Some preliminary analyses were performed in the first place. Primarily, in assessing the univariate skewness and kurtosis for each construct, an acceptable level of data distribution was detected. The reliability of each construct, as indicated by the Cronbach's alpha values, was well above the threshold value of 0.7 (Nunnally 1978). Further, both the KaiserMeyer-Olkin (KMO) index and Bartlett's test of sphericity were computed to determine the sufficiency of the data set for exploratory factor analysis (EFA) (Chu \& Murrmann 2006). The result, with a KMO index of 0.885 and Bartlett's sphericity test of high significance $(p<0.001)$, indicated the appropriateness of EFA in the subsequent analysis. In this regard, a principal component method with oblique rotation was performed for all the measures to examine their respective factor structures. Regardless of the theoretical underpinning, Hair et al. (2006) suggested the removal of an item if: (1) its factor loading is less than 0.5, (2) it cross-loads in two different groups at a time or (3) it loads in a group that it does not belongs to. Accordingly, two items from MO constructs and three items from OL constructs were dropped. While the OL construct was restructured into two new related groups, the remaining indicators (i.e. three components of $\mathrm{MO}$, two non-technical innovation types and two metrics of entrepreneurship) have loaded on their respective latent construct as expected. In the next step, all the multi-item constructs were assessed by confirmatory factor analysis (CFA) using partial least square (PLS) path modelling.

\section{Measurement model analysis}

The fitting index of measurement for each construct was computed via CFA. To assess the composite reliability, the factor loadings of each item should be above the suggested threshold of 0.708 (Hair et al. 2014). Accordingly, one item in the construct of $\mathrm{MO}$ and three items in the construct of OL were dropped due to low and insignificant factor loadings. As recommended by Nunnally (1978), all the multi-item constructs should fit a minimum value of 0.8 for the demonstration of construct reliability. Ranging from 0.86 to 0.90 (Table 1), the result indicated good reliabilities across the measures. Meanwhile, the average variance extract (AVE) values of the key constructs were higher than 0.5 (Fornell \& Larcker 1981) and therefore in support of convergent validity. Finally, the discriminant validity was determined by the 
TABLE 1: Measurement model results $(N=155)$.

\begin{tabular}{|c|c|c|c|c|c|c|c|c|c|c|}
\hline Construct & $\begin{array}{l}\text { Items in } \\
\text { scale }\end{array}$ & Mean & $\begin{array}{l}\text { Standard } \\
\text { deviation }\end{array}$ & $\begin{array}{l}\text { Average variance } \\
\text { extracted }\end{array}$ & $\begin{array}{c}\text { Cronbach's alpha } \\
\text { (composite reliability) }\end{array}$ & $\begin{array}{c}\text { Market } \\
\text { orientation }\end{array}$ & $\begin{array}{l}\text { Organisational } \\
\text { learning }\end{array}$ & $\begin{array}{l}\text { Marketing } \\
\text { innovation }\end{array}$ & $\begin{array}{c}\text { Organisational } \\
\text { innovation }\end{array}$ & Entrepreneurship \\
\hline Market orientation & 9 & 3.8 & 0.83 & 0.53 & $0.79 / 0.86$ & -0.73 & - & - & - & - \\
\hline Organisational learning & 10 & 3.8 & 0.81 & 0.50 & $0.83 / 0.89$ & 0.70 & -0.71 & - & - & - \\
\hline Marketing innovation & 4 & 3.8 & 0.94 & 0.71 & $0.86 / 0.90$ & 0.66 & 0.62 & -0.84 & - & - \\
\hline Organisational innovation & 4 & 3.5 & 0.85 & 0.69 & $0.86 / 0.89$ & 0.71 & 0.70 & 0.72 & -0.83 & - \\
\hline Entrepreneurship & 7 & 3.7 & 0.76 & 0.60 & $0.87 / 0.90$ & 0.69 & 0.66 & 0.66 & 0.67 & -0.77 \\
\hline
\end{tabular}

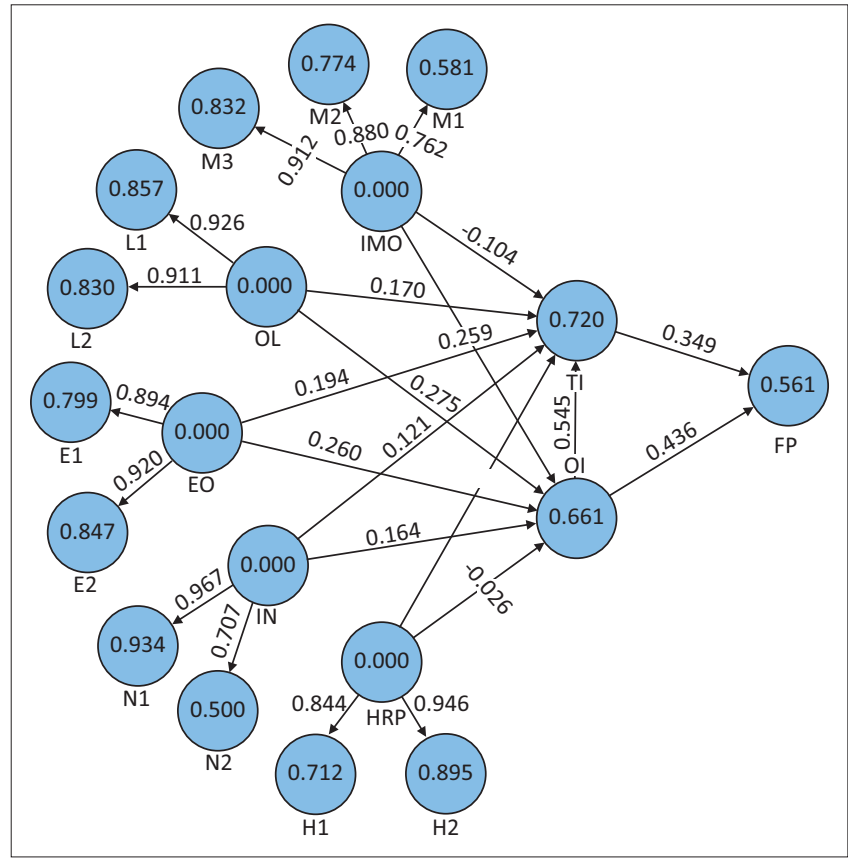

IMO, integrated market orientation; OL, organisational learning; HRP, human resource practice; EO, entrepreneurship; FP, entrepreneurship; TI, technological innovation.

FIGURE 2: Partial least squares structural equation modelling framework of innovation for small-size project-based service firms.

value of the key construct in its square root of AVE (SQRT AVE) to be greater than its correlation with any other factors in the framework (Hair et al. 2006). The result, diagonal from 0.71 to 0.84 , showed adequate discriminant validity for each construct. Table 1 presented the specification of the adequacy of the measurement model in all cases.

\section{Structural model analysis}

Rather than goodness-of-fit indices (Henseler \& Sarstedt 2013), the robustness of a structural model is computed via its explanatory power on the hypothesised paths (Hair et al. 2014). Both MO and OL are the exogenous constructs, with organisational and marketing innovation as the intermediate endogenous constructs, and entrepreneurship as the endogenous outcome. As indicated in Figure 2, the square multiple correlations $\left(R^{2}\right)$ value of the structural model revealed a very satisfactory level of predictability for the framework. The respective $\mathrm{R}^{2}$ value for the intermediate endogenous constructs (i.e. organisational innovation $=0.65$; marketing innovation $=0.48$ ) and the endogenous latent constructs (i.e. entrepreneurship $=0.52$ ) largely exceeded the 0.1 threshold value (Falk \& Miller 1992).

Next, each standardised path coefficient $(\beta)$ and the associated $\mathrm{t}$-values of each latent construct were examined (as indicated
TABLE 2: Structural equation model results.

\begin{tabular}{|c|c|c|c|}
\hline Variable & Path coefficient & $t$-value & Conclusion \\
\hline \multicolumn{4}{|l|}{ Hypothesised links } \\
\hline $\begin{array}{l}\text { Market orientation } \rightarrow \\
\text { Entrepreneurship }\end{array}$ & $0.254^{*}$ & 2.6445 & H1 supported \\
\hline $\begin{array}{l}\text { Organisational learning } \rightarrow \\
\text { Entrepreneurship }\end{array}$ & $0.172 \dagger$ & 1.6753 & H2 not supported \\
\hline $\begin{array}{l}\text { Market orientation } \rightarrow \\
\text { Organisational learning }\end{array}$ & $0.755 * *$ & 19.7086 & H3 supported \\
\hline $\begin{array}{l}\text { Market orientation } \rightarrow \\
\text { Organisational innovation }\end{array}$ & $0.206^{*}$ & 2.4348 & H4 supported \\
\hline $\begin{array}{l}\text { Market orientation } \rightarrow \\
\text { Marketing innovation }\end{array}$ & $0.447 * *$ & 4.7557 & H5 supported \\
\hline $\begin{array}{l}\text { Organisational learning } \rightarrow \\
\text { Organisational innovation }\end{array}$ & $0.325 * *$ & 4.9368 & H6 supported \\
\hline $\begin{array}{l}\text { Organisational learning } \rightarrow \\
\text { Marketing innovation }\end{array}$ & $0.285 * *$ & 3.1817 & H7 supported \\
\hline $\begin{array}{l}\text { Organisational innovation } \rightarrow \\
\text { Entrepreneurship }\end{array}$ & $0.208^{*}$ & 2.4821 & H8 supported \\
\hline $\begin{array}{l}\text { Marketing innovation } \rightarrow \\
\text { Entrepreneurship }\end{array}$ & $0.232 * *$ & 3.1712 & H9 supported \\
\hline Age $\rightarrow$ Entrepreneurship & $0.067 \dagger$ & 1.5814 & - \\
\hline \multicolumn{4}{|l|}{ Non-hypothesised links } \\
\hline $\begin{array}{l}\text { Marketing innovation } \rightarrow \\
\text { Organisational innovation }\end{array}$ & $0.376 * *$ & 5.0134 & - \\
\hline
\end{tabular}
Organisational innovation

$\dagger$, not significant.

$*, p<0.01 ; * *, p<0.001$

in Table 2). Accordingly, $\mathrm{MO}$ has a moderate significant positive effect on entrepreneurship $(\beta=0.25, t=2.644)$, supporting H1. A strong and significant positive effect exists between MO and OL $(\beta=0.76, t=19.708)$, supporting $\mathrm{H} 3$. The significant effect of $\mathrm{MO}$ on organisational innovation $(\beta=0.21, t=2.435)$ and marketing innovation $(\beta=0.45$, $t=4.756$ ) supports $\mathrm{H} 4$ and $\mathrm{H} 5$. Organisational learning has a significant positive effect on organisational innovation $(\beta=0.33, t=4.937)$ and marketing innovation $(\beta=0.29$, $t=3.181$ ), supporting $\mathrm{H} 6$ and $\mathrm{H} 7$. The effects of organisational innovation $(\beta=0.21, t=2.482)$ and marketing innovation $(\beta=0.23, t=3.171)$ on entrepreneurship are also significant, giving support to $\mathrm{H} 8$ and $\mathrm{H} 9$. Contrary to prediction, however, no support is indicated for the hypothesised path of OL and entrepreneurship (H2). The control variable of firm age was significant as well. Nevertheless, an interesting significant effect is detected between marketing innovation and organisational innovation $(\beta=0.38, t=5.013)$.

Beyond the direct hypothesised paths, the present study disentangled the indirect paths to understand the mediating function of non-technical innovation in its causal relationships with its antecedents and consequences. Consistent with Cheng and Krumwiede's (2012) recommended componentwise procedure, we dismantle each of the key constructs into their respective components to better scrutinise the specific mediated effects of the mediators. The significance of each path was computed using the Sobel test (Preacher \& Hayes 


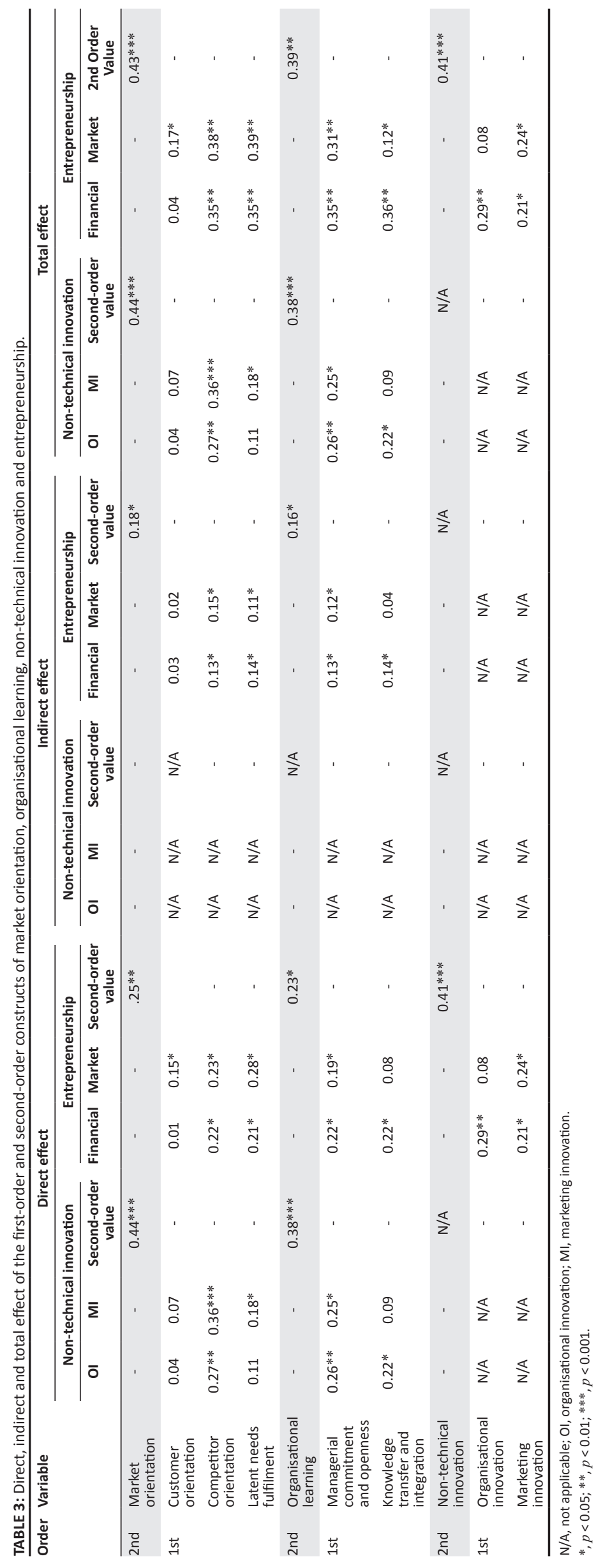


2008) assisted with bootstrapping procedure. As indicated in Table 3, both the first-order and second-order analysis of structural models offered support for the existence of a mediation effect in the proposed framework. For instance, in observing the second-order structural model, the path of market orientation to entrepreneurship significantly indicated a direct effect $(\beta=0.25, p<0.01)$ and an indirect effect $(\beta=0.18, p<0.05)$. Similarly in the path of organisational learning to entrepreneurship, the direct effect $(\beta=0.17, p<0.05)$ and indirect effect $(\beta=0.16, p<0.05)$ are statistically significant. Further to this line of assessment, the variance accounted for (VAF) in the proposed model was computed to determine the mediating strength of the mediator. The respective variances of less than $20 \%$, between $20 \%$ and $80 \%$, or more than $80 \%$ equate to no mediation, partial mediation and full mediation (Hair et al. 2014). As such, non-technical innovation was observed to exert a partial mediating effect in both MO to entrepreneurship $(\mathrm{VAF}=42 \%)$ and OL to entrepreneurship $(\mathrm{VAF}=41 \%)$ paths.

Figure 2 presents the developed structural model of innovation based on the quantitative strand. Through the use of PLS structural equation modelling, the structural model indicated the factors that significantly relate to innovation practices of the firms. These included organisational capabilities (all except human resource practice construct), innovations (include both technological and organisational innovation activities) and entrepreneurship. Importantly, it depicted that firms affiliated with certain capabilities could competently pursue the undertaking of innovations across projects and within the firm to acquire higher performance.

Moving a step further into the first-order structural model, several interesting findings were suggested (Table 3). Under the MO construct, customer orientation was insignificantly associated with both financial performance $(\beta=0.03)$ and market performance $(\beta=0.02)$, suggesting no mediation in the paths. Meanwhile, competitor orientation was significantly and positively related to financial performance $(\beta=0.13, p<0.05)$ and market performance $(\beta=0.15, p<0.05)$, both of which, in turn, imply partial mediated effects in the paths. Likewise, the indirect effects of latent needs fulfilment regarding financial performance $(\beta=0.14, p<0.05)$ and market performance $(\beta=0.11, p<0.05)$ were significant, suggesting partial mediation as well. Under the OL construct, managerial commitment and openness were significantly related to financial performance $(\beta=0.13, p<0.05)$ and market performance $(\beta=0.12, p<0.05)$, suggesting partial mediated effects in the paths. Additionally, knowledge transfer and integration had a significant indirect effect on financial performance $(\beta=0.17, p<0.05)$ but a non-significant effect on market performance $(\beta=0.04)$. Figure 3 presents the structural equation model.

\section{Full model of innovation}

The optimum number of extracted components for each key construct was determined. Traditional methods included a latent root test (that identified all factors to have eigenvalues $>1$ ) a scree test (that examines the cut-off point in the curve graph). A syntax named 'Tsplot' was conducted for parallel analysis, which was a plot with horizontal lines crossing the main line of the eigenvalue. The number of factors lying above the crossing lines determining the appropriate number of extracted factors. The parallel analysis was used to determine the appropriate number of extracted factors for all eight the constructs, including: integrated market orientation (IMO), organisational learning (OL), human resource practice (HRP), entrepreneurship (EO), interorganisational network (IN), technological innovation (TI), organisational innovation (OI) and entrepreneurship (FP). As depicted in Figure 4, only factors lying above the extraction line were considered. The $y$-axis denotes the eigenvalue while the $x$-axis denotes the number of variables. Appendix G showed O'Connor's syntax and the steps of conducting parallel analysis.

Via the PLS technique, the full model was depicted by connecting all constructs according to the conceptual

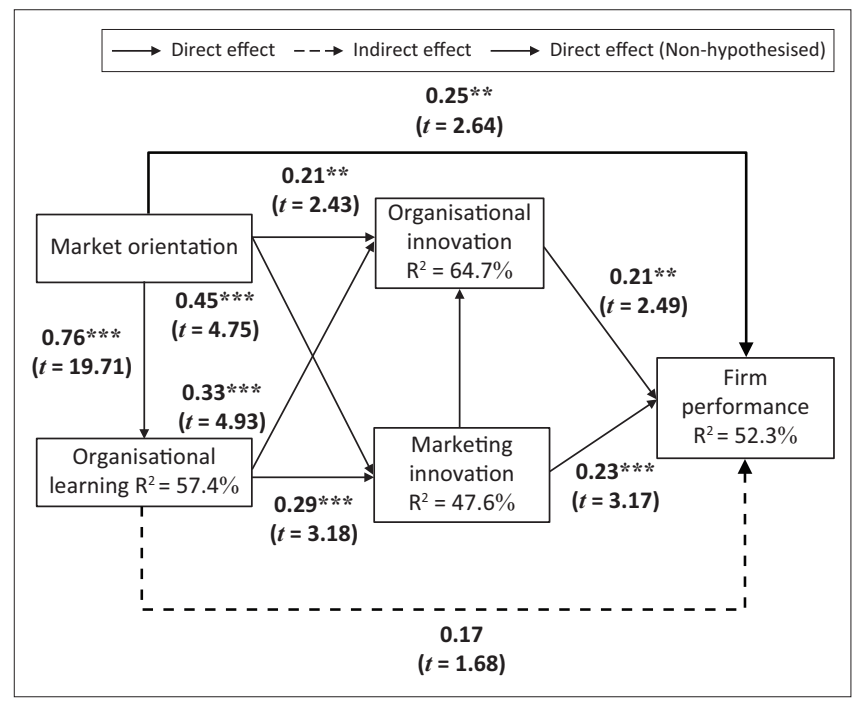

$*, p<0.05$ (two tailed); **, $p<0.01 ; * * *, p<0.001$.

FIGURE 3: Structural equation model of non-technical innovation, market orientation and organisational learning with managerial performance in smallsize project-based service firms.

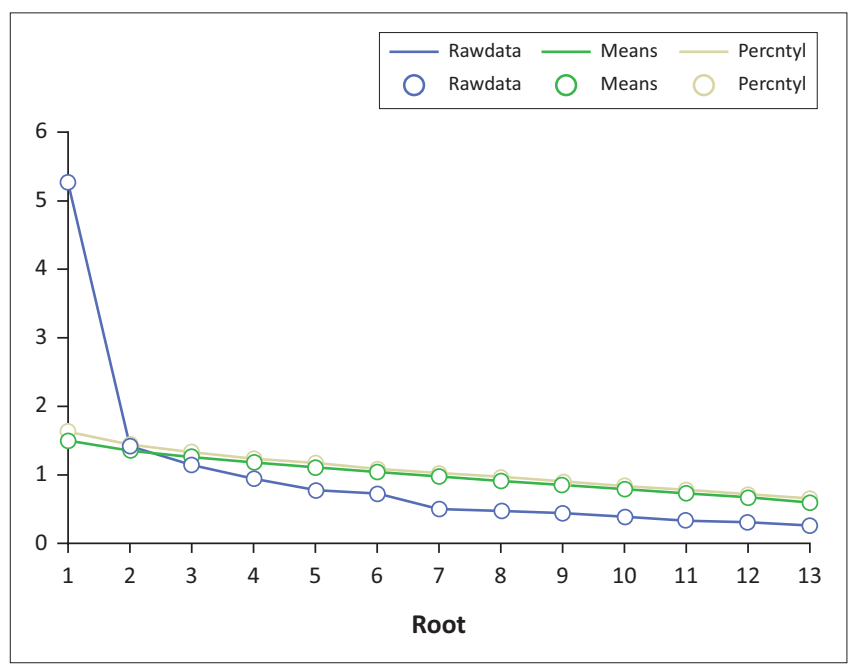

FIGURE 4: Tsplot for constructs in parallel analysis. 
model. All manifest variables were assigned to their latent constructs based on the results of analyses in the previous sections. As shown in Figure 5, the full model comprised both measurement and structural models. The measurements models displayed the relationship between the constructs (i.e. circles) and the indicator variables (i.e. rectangles) while the structural model displayed the relationship (or paths) between the constructs (e.g. OL and TI; TI and FP, etc.). The current study used the following criteria to run the algorithm in PLS to obtain the results of the full model:

- Weighting scheme: Path weighting scheme

- Data metric: Mean 0, Var 1 (the default in the program, to ensure normality)

- Maximum iterations: 300 (the default in the program)

- Abort criterion: 1.0E-5 (the default in the program)

- Initial weight: 1 (the default in the program)

\section{Discussion and implementation}

Overall, the survey results of 155 service firms engaging in project delivery were in support of the proposed conceptual framework. For project-based firms with size-based vulnerability, non-technical innovation provides firms with beneficial value in performance terms. Specifically, the internally established capabilities of market orientation and organisational learning were both pivotal antecedents in favour of entrepreneurship through varying mediators of non-technical innovation. By means of a non-technical approach, the present study suggested some motivational implications to both the theorists and practitioners.

\section{Theoretically implication}

This study has informed several new insights to academic research. Firstly, unlike previous studies that predominantly

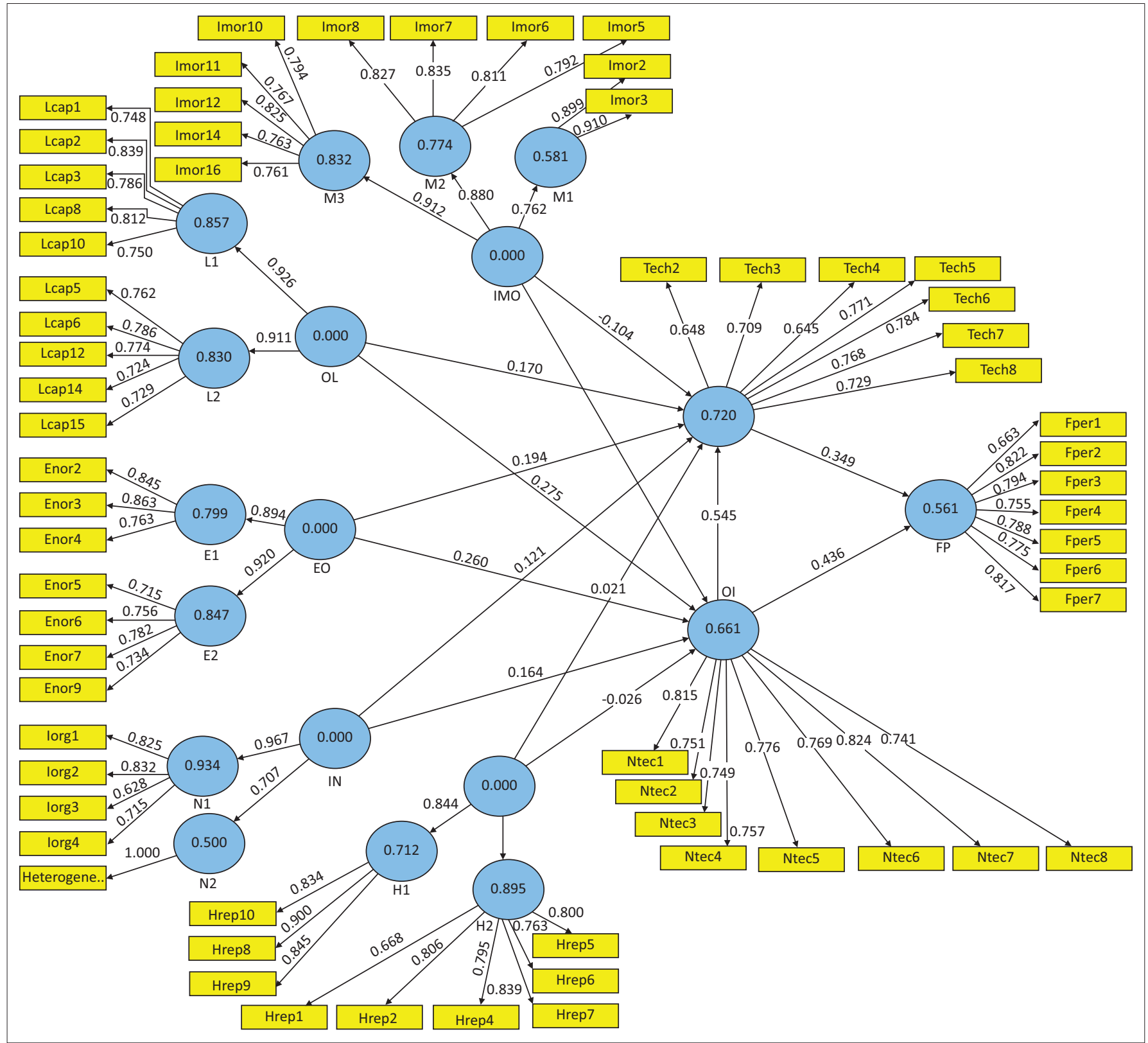

FIGURE 5: Full model of innovation (extending the manifest variables). 
anchored on the technical sense of innovation, this study examines the offerings of non-technical innovation by specifically drawing their relation with the firm's capabilities. Based on the empirical results, capabilities are important determinants of non-technical innovation. Both marketoriented and learning postures, as disclosed in their mutually complementary effects $(\beta=0.76, t=19.709)$, synergistically spur on the coupled development of non-technical innovation. Remarkably, the leverage of market-oriented efforts within the learning perspective not only favours the growth of technical innovation (Hurley \& Hult 1998; Lertpachin et al. 2013; Nasution \& Mavondo 2008), but also constitutes impetus for new organisational and marketing practices. These findings have unlocked interesting extensions to previous works (Camison \& Villar-Lopez 2011; Weerawardena, 2003; Weerawardena et al. 2006) that advocate the antecedent role of the firm's capabilities in exploiting the novel value creation within the framework of non-technical initiatives.

Secondly, this study advances the inconclusive empirical findings that have sought to model non-technical innovation in affiliation with the preponderance of business performance. As noted earlier, the innovation literature frequently interweaves entrepreneurship with diverse types of outcome metrics. Featuring entrepreneurship in both financial and market forms, as depicted in the major stream of empirical research (Cheng \& Krumwiede 2012; Matear et al. 2002; Shergill \& Nargundkar 2005), the result reveals the nearly significant positive effect between the two varying non-technical innovation dimensions with regard to entrepreneurship. Specifically, organisational innovation $(\beta=0.21, t=2.486)$ and marketing innovation $(\beta=0.23$, $t=3.171$ ) play a favouring role in engendering beneficial sources of opportunities that directly impact on business performance. In addition to this line of evidence, both innovative approaches unravel their interdependent linkage $(\beta=0.38, t=5.013)$ in further establishing the performance breadth. As stressed by Gambatese and Hallowell (2011), some innovations have intangibly occurred throughout routine business activities although they are more difficult to recognise in contrast to tangible product-based innovations. Our study represents a supporting response to the call of Brochner (2010) for the inclusion of non-technical innovation in a setting that captures small firms' pursuit of innovationbased performance.

Thirdly, this study specifically scrutinised the potential mediating impact of non-technical innovation in the capabilities-performance linkage. In particular, the findings were in contrast to earlier studies that ued customers' explicit thoughts as the basis of innovative capability among small and medium enterprises (Akman \& Cengiz 2008). In contrast, non-technical innovative offerings were observed to substantiate beneficial entrepreneurship through firms' efforts to adapt to implicit customer expectations and integrate knowledge linkages across peer competitors. Similar results were found in prior studies that captured organisational business advantage in affiliation with the appropriate input of latent needs of customers (Nasution \& Mavondo 2008) and competitor orientation (Cheng \& Krumwiede 2012). Likewise, the favouring role of non-technical innovation is found to partially intertwine with both the components of managerial commitment and openness, as well as knowledge transfer and integration in relation to entrepreneurship. In this regard, the sturdier the integral trait of project-centred learning at the firm level, the greater the performance value sustained in firms (Manley 2008; Salunke et al. 2011). The current study presents more refined findings in discerning the impact of innovative offerings upon their antecedents and consequences.

\section{Managerial implication}

Notably, the findings offer valuable implications for small service firms. To secure new service offerings, managers should pay special attention to the role of non-technical innovation in connection with both organisational and marketing dimensions. Specifically, given the constrained resources and uncertain site-based operations, firms affiliated with certain strategic capabilities could competently pursue the undertaking of non-technical innovation. Managerial emphasis should therefore persistently deploy to seize new marketplace opportunities in alignment with various active learning-based practices. Accordingly, both $\mathrm{MO}$ and OL need to be considered, interdependently, in enabling the non-technical feasibility of innovation delivery. In addition, non-technical innovation has emerged as a favourable source for the overall success of business performance. Even with finite resources, managers should strive to capitalise the two distinctive types of innovation while concatenating them into routine business operation and project activities, without which superior firm success is difficult to underpin. Our thorough empirical analysis should enlighten practitioners that new service offerings should not be based solely on a product and process viewpoint, but organisational and marketing prospects should be included in strategic innovation.

\section{Conclusion and recommendations}

In conclusion, this research provides worthy insights for both scholars and practitioners. In considering the criticality of innovation as the fulcrum of service-based delivery, our model advances the existing empirical approaches with a more intangible dimensionality of innovative efforts. Overall, the model distinguishes that small service firms engaging in dual modes of non-technical innovation strategically nurture intangible capabilities which in turn provides them with enduring performance outcomes in outperforming competitors. Nonetheless, it presents several limitations and holds great opportunities for future research. Firstly, the design of the cross-sectional analysis in the present study impedes a full consideration of the causality between constructs. Future research should apply longitudinal analysis to enable higher accuracy in examining the causal nature of the relationships. Secondly, the findings are derived 
within project-based contexts, which demands caution in generalising our findings as with assessing their applicability to other service sectors. Replication of this research in other countries should help to verify the applicability of the results of this study for other parts of the world. Also, how does non-technical innovation complement the higher degree of technical innovative practices across portfolios of projects? How do large and small organisations vary in their central routine activities in seeking a different range of innovative endeavours? Further research should test these questions to better understand the existing non-technical offerings and the potential benefits of adding non-technical services to actual offerings.

\section{Acknowledgements Competing interests}

The authors have declared that no competing interests exist.

\section{Authors' contributions}

All authors contributed equally to this work.

\section{Funding information}

This research was funded by Huaqiao University, grant number 17BS201, Quanzhou City Government, grant number 600005-Z17X0234, and Quanzhou science and technology bureau, grant number 2018Z010.

\section{Ethical consideration}

This article followed all ethical standards for carrying out research without direct contact with human or animal subjects.

\section{Data availability statement}

Data sharing is not applicable to this article as no new data were created or analysed in this study.

\section{Disclaimer}

The views and opinions expressed in this article are those of the authors and do not necessarily reflect the official policy or position of any affiliated agency of the authors.

\section{References}

Acs, Z.J. \& Audretsch, D.B., 1988, 'Innovation in large and small firms: An empirical analysis', American Economic Review 78(4), 678-690.

Akman, G. \& Cengiz, Y., 2008, 'Innovative capability, innovation strategy, and market orientation: An empirical analysis in Turkish software industry', International Journal of Innovation Management 12(1), 69-111. https://doi.org/10.1142/ Journal of Innovation

Alam, I., 2002, 'An exploratory investigation of user involvement in new service development', Journal of the Academy of Marketing Science 30(3), 250-261. https://doi.org/10.1177/0092070302303006

Alegre, J. \& Chiva, R., 2008, 'Assessing the impact of organizational learning capability on product innovation performance: An empirical test', Technovation 28(6), 315-326. https://doi.org/10.1016/j.technovation.2007.09.003

Aravind, D., Damanpour, F. \& Devece, C., 2014, 'Environmental performance: Interplay between the roles of process innovation capability and managerial innovation implementation', in J.L. Hervas-Oliver \& M. Peris-Ortiz (eds.), Managemen innovation: Antecedents, complementarities and performance consequences, pp. 29-43, Springer International Publishing AG, Cham.
Armbruster, H., Kirner, E., Lay, G., Szwejczewski, M., Corita, B., Leguehennec, C., et al., 2006, Patterns of organisational change in European industry (PORCH). Ways to strengthen the empirical basis of research and policy, Fraunhofer Institute of Systems and Innovation Research, Karlsruhe.

Armstrong, J.S. \& Overton, T., 1977, 'Estimating non response bias in mail surveys', Journal of Marketing Research 14(3), 396-402. https://doi.org/10.1177/ 002224377701400320

Baker, W.E. \& Sinkula, J.M., 1999, 'The synergistic effect of market orientation and learning orientation on organizational performance', Journal of the Academy of Marketing Science 27(4), 411-427. https://doi.org/10.1177/0092070399274002

Birkinshaw, J. \& Mol, M., 2006, 'How management innovation happens', MIT Sloan Review 47(4), 81-88.

Brochner, J., 2010, 'Construction contractors as service innovators', Building Research and Information 38(3), 235-246. https://doi.org/10.1080/09613211003616706

Camison, C. \& Villar-Lopez, A., 2011, 'Non-technical innovation: Organizational memory and learning capabilities as antecedent factors with effects on sustained competitive advantage', Industrial Marketing Management 40(8), 1294-1304. https://doi.org/10.1016/j.indmarman.2011.10.001

Camison, C. \& Villar-Lopez, A., 2014, 'Organizational innovation as an enabler of technological innovation capabilities and firm performance', Journal of Business Research 67(1), 2891-2902. https://doi.org/10.1016/j.jbusres.2012.06.004

Cappelli, P. \& Neumark, D., 2001, 'Do "high-performance" work practices improve establishment level outcomes?' Industrial and Labor Relations Review 54(4), 737-776. https://doi.org/10.3386/w7374

Caroli, E. \& Van Reenen, J., 2001,'Skill biased organisational change: Evidence from a panel of British and French establishments', Quarterly Journal of Economics 116(4), 1149-1192. https://doi.org/10.1162/003355301753265624

Cheng, C.C. \& Krumwiede, D., 2012, 'The role of service innovation in the marketorientation - New service performance linkage', Technovation 32(Suppl 7-8), 487-497. https://doi.org/10.1016/j.technovation.2012.03.006

Chu, K.H. \& Murrmann, S.K., 2006, 'Development and validation of the hospitality emotional labor scale', Journal of Hospitality \& Tourism Research 27(6) 1181-1191. https://doi.org/10.1016/j.tourman.2005.12.011

Coskun, H., Erdis, E. \& Demirci, M., 2013, 'Pricing policies as a marketing strategy in the construction industry: Case study of Turkish companies', Technological and Economic Development of Economy 19(Suppl 1), S1-S21. https://doi.org/10.3846 /20294913.2013.821688

Davies, A., Manning, S. \& Söderlund, J., 2018, 'When neighboring disciplines fail to learn from each other: The case of innovation and project management research', Research Policy 47(5), 965-979. https://doi.org/10.1016/j.respol.2018.03.002

Day, G.S., 1994, 'The capabilities of market-driven organizations', Journal of Marketing 58(4), 37-52. https://doi.org/10.2307/1251915

Deshpande, R., Farley, J.W. \& Webster, F.E.J., 1993, 'Corporate culture, customer orientation, and innovativeness in Japanese firms: A quadrad analysis', Journal of Marketing 57(1), 27-37. https://doi.org/10.2307/1252055

DiBella, A.J., 1995, 'Developing learning organizations: A matter of perspective', Academy of Management Journal: Best Papers Proceedings 1995(1), 287-290. https://doi.org/10.5465/ambpp.1995.17536560

Dibrell, C., Craig, J.B. \& Hansen, E.N., 2011, 'How managerial attitudes toward the natural environment affect market orientation and innovation', Journal of Business Research 64(4), 401-407. https://doi.org/10.1016/j.jbusres.2010.09.013

Dikmen, I., Birgonul, M.T. \& Ozcenk, I., 2005, 'Marketing orientation in construction firms: Evidence from Turkish contractors', Building and Environment 40(2) 257-265. https://doi.org/10.1016/j.buildenv.2004.07.009

Drejer, I., 2004, 'Identifying innovation in surveys of services: A Schumpeterian perspective', Research Policy 33(3), 551-562. https://doi.org/10.1016/j.respol. 2003.07.004

Drejer, I. \& Vinding, A.L., 2006, “Organisation, "anchoring" of knowledge, and innovative activity in construction', Construction Management and Economics 24(9), 921-931. https://doi.org/10.1080/01446190600799166

Evangelista, R. \& Vezzani, A., 2010, 'The economic impact of technological and organisational innovations: A firm-level analysis', Research Policy 39(10), 1253-1263. https://doi.org/10.1016/j.respol.2010.08.004

Falk, R.F. \& Miller, N.B., 1992, A primer for soft modelling, The University of Akron, Akron, $\mathrm{OH}$.

Farrell, M.A. \& Oczkowski, E., 2002, 'Are market orientation and learning orientation necessary for superior organizational performance?' Journal of Market Focused Management 5(3), 197-217. https://doi.org/10.1023/A:1022990622706

Fernandez, A., Roy, F. \& Chiambaretto, P., 2018, 'Implementing the right project structure to achieve coopetitive innovation projects', Long Range Planning 51(2), 384-405. https://doi.org/10.1016/j.Irp.2017.07.009

Fornell, C. \& Larcker, D., 1981, 'Evaluating structural equation models with unobservable variables and measurement error', Journal of Marketing Research 18(1), 39-50. https://doi.org/10.2307/3151312

Gallego, J. \& Rubalcaba, L., 2012, 'Organizational innovation in small European firms: A multidimensional approach', International Small Business Journal 31(5), 563-579. https://doi.org/10.1177/0266242611430100

Gambatese, J.A. \& Hallowell, M., 2011, 'Enabling and measuring innovation in the construction industry', Construction Management and Economics 29(6), 553-567. https://doi.org/10.1080/01446193.2011.570357

Gann, D.M. \& Salter, A.J., 2000, 'Innovation in project based, service enhanced firms: The construction of complex products and systems', Research Policy 29(7-8), 955-972. https://doi.org/10.1016/S0048-7333(00)00114-1 
Greenan, N., 2003, 'Organisational change, technology, employment and skills: An empirical study of French manufacturing', Cambridge Journal of Economics 27(2), 287-316. https://doi.org/10.1093/cje/27.2.287

Hair, J., Hult, G., Ringle, C. \& Sarstedt, M., 2014, A primer on partial least square structural equation modelling (PLS-SEM), Sage Publication, Thousand Oaks, CA.

Hair, J., Tatham, R., Anderson, R. \& Black, W., 2006, Multivariate data analysis, 5th edn., Prentice-Hall, Upper Saddle River, NJ.

Hakansson, H. \& Ingemansson, M., 2013, 'Industrial renewal within the construction network', Construction Management and Economics 31(1), 40-61. https://doi org/10.1080/01446193.2012.737470

Hamel, G., 2006, 'The why, what and how of management innovation', Harvard Business Review 84(2), 72-84.

Hamel, G. \& Prahalad, C.K., 1994, Competing for the future, Harvard Business Schoo Press, Boston, MA

Han, J., Kim, N. \& Srivastava, R., 1998, 'Market orientation and organisational performance: Is innovation a missing link?' Journal of Marketing 62(4), 30-46. https://doi.org/10.2307/1252285

Hauser, J., Tellis, G.J. \& Griffin, A., 2006, 'Research on innovation: A review and agenda for marketing science', Marketing Science 25(6), 687-717. https://doi.org/10. $1287 /$ mksc.1050.0144

Henseler, J. \& Sarstedt, M., 2013, 'Goodness-of-fit indices for partial least squares path modeling', Computational Statistics 28(2), 565-580. https://doi.org/10.1007/ s00180-012-0317-1

Hipp, C. \& Grupp, H., 2005, 'Innovation in the service sector: The demand for service specific innovation measurement concepts and typologies', Research Policy 34(4), 517-535. https://doi.org/10.1016/j.respol.2005.03.002

Hult, G.T.M., Hurley, R.F. \& Knight, G.A., 2004, 'Innovativeness: Its antecedents and impact on business performance', Industrial Marketing Management 33(5), 429-438. https://doi.org/10.1016/j.indmarman.2003.08.015

Hurley, R.F. \& Hult, G.T.M., 1998, 'Innovation, market orientation, and organizational learning: An integration and empirical examination', Journal of Marketing 62(3), 42-54. https://doi.org/10.2307/1251742

Iliescu, M. \& Ciocan, R., 2017, 'Modern technologies innovation in use for quality control on construction site', Procedia Engineering 181(1), 999-1004. https://doi. org/10.1016/j.proeng.2017.02.499

Im, S. \& Workman, J., 2004, 'Market orientation, creativity, and new product performance in high-technology firms', Journal of Marketing 68(2), 114-132. https://doi.org/10.1509/jmkg.68.2.114.27788

Jerez-Gomez, P., Cespedes-Lorente, J. \& Valle-Cabrera, R., 2005, 'Organizational learning capability: A proposal of measurement', Journal of Business Research 58(6), 715-725. https://doi.org/10.1016/j.jbusres.2003.11.002

Jimenez-Jimenez, D. \& Sanz-Valle, R., 2011, 'Innovation, organizational learning and performance', Journal of Business Research 64(4), 408-417. https://doi. org/10.1016/j.jbusres.2010.09.010

Keskin, H., 2006, 'Market orientation, learning orientation, and innovation capabilities in SMEs: An extended model', European Journal of Innovation Management 9(4), 396-417. https://doi.org/10.1108/14601060610707849

Kindstrom, D., Kowalkowski, C. \& Sandberg, E., 2013, 'Enabling service innovation: A dynamic capabilities approach', Journal of Business Research 66(8), 1063-1073. https://doi.org/10.1016/j.jbusres.2012.03.003

Kohli, A.K. \& Jaworski, B.J., 1990, 'Market orientation: The construct, research propositions and managerial implications', Journal of Marketing 54(2), 1-18. https://doi.org/10.2307/1251866

Lechner, C., Dowling, M. \& Welpe, I., 2006, 'Firm networks and firm development: The role of the relational mix', Journal of Business Venturing 21(4), 514-540. https:// doi.org/10.1016/j.jbusvent.2005.02.004

Lee, C.K., Tan, B. \& Chiu, J.Z., 2008, 'The impact of organisational culture and learning on innovation performance', International Journal of Innovation and Learning 5(4), 413-418. https://doi.org/10.1504/IJIL.2008.017561

Lertpachin, C., Wingwon, B. \& Noithonglek, T., 2013, 'The effect of marketing focus, innovation and learning organization on the building of competitive advantage: Empirical evidence from ISO 9000 certified companies', Journal of Strategic Marketing 21(4), 323-331. https://doi.org/10.1080/0965254X.2013.790469

Lettice, F., Tschida, M. \& Forstenlechner, I., 2014, 'Managing in an economic crisis: The role of market orientation in an international law firm', Journal of Busines Research 67(1), 2693-2700. https://doi.org/10.1016/j.jbusres.2013.03.018

Manley, K., 2008, 'Against the odds: Small firms in Australia successfully introducing new technology on construction projects', Research Policy 37(10), 1751-1764. https://doi.org/10.1016/j.respol.2008.07.013

Martínez-Román, J.A., Tamayo, J.A. \& Gamero, J., 2017, 'Innovativeness and its influence on growth and market extension in construction firms in the Andalusian region', Journal of Engineering and Technology Management 43(1), 19-33. https://doi.org/10.1016/j.jengtecman.2016.11.002

Matear, S., Osborne, P., Garrett, T. \& Gray, B., 2002, 'How does market orientation contribute to service firm performance? An examination of alternative mechanisms', European Journal of Marketing 36(9/10), 1058-1075. https://doi. org/10.1108/03090560210437334

Mazzanti, M., Pini, P. \& Tortia, E., 2006, 'Organizational innovations, human resources and firm performance: The Emilia-Romagna food sector', The Journal of SocioEconomics 35(1), 123-141. https://doi.org/10.1016/j.socec.2005.12.007

Mol, M.J. \& Birkinshaw, J., 2009, 'The sources of management innovation: When firms introduce new management practices', Journal of Business Research 62(2), 1269-1280. https://doi.org/10.1016/j.jbusres.2009.01.001
Naidoo, V., 2010, 'Firm survival through a crisis: The influence of market orientation, marketing innovation and business strategy', Industrial Marketing Management 39(8), 1311-1320. https://doi.org/10.1016/j.indmarman.2010. Manage
02.005

Narver, J.C. \& Slater, S.F., 1990, 'The effect of a market orientation on business profitability', Journal of Marketing 54(4), 20-35. https://doi.org/10. profitability',
$2307 / 1251757$

Nasution, H.N. \& Mavondo, F.T., 2008, 'Organizational capabilities: Antecedents and implications for customer value', European Journal of Marketing 42(3/4) 477-501. https://doi.org/10.1108/03090560810853020

Nunnally, J.C., 1978, Psychometric theory, McGraw-Hill, New York, NY.

Nyström, J., Nilsson, J. \& Lind, H., 2016, 'Degrees of freedom and innovations in construction contracts', Transport Policy 47(1), 119-126. https://doi.org/10. 1016/j.tranpol.2016.01.004

O'Cass, A., Song, M. \& Yuan, L., 2013, 'Anatomy of service innovation: Introduction to the special issue', Journal of Business Research 66(8), 1060-1062. https://doi. org/10.1016/j.jbusres.2012.03.002

OECD, 2005, Oslo manual. Guidelines for collecting and interpreting innovation data 3rd edn., OECD EUROSTAT, Paris.

Pelham, A.M., 1999, 'Influence of environment, strategy, and market orientation on performance in small manufacturing firms', Journal of Business Research 45(1) 33-46. https://doi.org/10.1016/S0148-2963(98)00026-5

Pellicer, E., Yepes, V., Correa, C.L. \& Alarcon, L.F., 2012, 'Organizational improvement through standardization of the innovation process in construction firms', Engineering Management Journal 24(2), 40-53. https://doi.org/10.1080/104292 47.2012.11431935

Pereira, C.S. \& Romero, F.C.C., 2013, 'Non-technological innovation: Current issues and perspectives', Independent Journal of Management and Production 4(1) 360-376. https://doi.org/10.14807/ijmp.v4i1.88

Pesamaa, O., Shoham, A., Wincent, J. \& Ruvio, A.A., 2013, 'How a learning orientation affects drivers of innovativeness and performance in service delivery', Journal of Engineering and Technology Management 30(2), 169-187. https://doi.org/10. 1016/j.jengtecman.2013.01.004

Preacher, K. \& Hayes, A., 2008, 'Asymptotic and resampling strategies for assessing and comparing indirect effects in multiple mediator models', Behavior Research Methods, Instruments \& Computers 40(3), 879-891. https://doi.org/10.3758/ BRM.40.3.879

Preeker, T. \& Giovanni, P.D., 2018, 'Coordinating innovation projects with high tech suppliers through contracts', Research Policy 47(6), 1161-1172. https://doi. org/10.1016/j.respol.2018.04.003

Raju, P.S., Lonial, S.C. \& Crum, M.D., 2011, 'Market orientation in the context of SMEs: A conceptual framework', Journal of Business Research 64(12), 1320-1326. https://doi.org/10.1016/j.jbusres.2010.12.002

Salavou, H., 2002, 'Profitability in market-oriented SMEs: Does product innovation matter?' European Journal of Innovation Management 5(3), 164-171. https://doi. org/10.1108/14601060210436736

Salunke, S., Weerawardena, J. \& McColl-Kennedy, J.R., 2011, 'Towards a model of dynamic capabilities in innovation-based competitive strategy: Insights from project-oriented service firms', Industrial Marketing Management 40(8), 1251-1263. https://doi.org/10.1016/j.indmarman.2011.10.009

Seaden, G., Guolla, M., Doutriaux, J. \& Nash, J., 2003, 'Strategic decisions and innovation in construction firms', Construction Management and Economics 21(6), 603-612. https://doi.org/10.1080/0144619032000134138

Shergill, G.S. \& Nargundkar, R., 2005, 'Market orientation, marketing innovation as performance drivers', Journal of Global Marketing 19(1), 27-47. https://doi. org/10.1300/J042v19n01_03

Sin, L.Y.M., Tse, A.C.B., Heung, V.C.S. \& Yim, F.H.K., 2005, 'An analysis of the relationship between market orientation and business performance in the hotel industry', International Journal of Hospitality Management 24(4), 555-577. https://doi. org/10.1016/j.ijhm.2004.11.002

Sinkula, J., 1994, 'Market information processing and organizational learning', Journal of Marketing 58(1), 35-45. https://doi.org/10.1177/002224299405800103

Sinkula, J.M., Baker, W.E. \& Noordeweir, T., 1997, 'A framework for market-based organizational learning: Linking values, knowledge, behavior', Journal of the Academy of Marketing Science 25(4), 305-318. https://doi.org/10.1177/ 0092070397254003

Slater, S. \& Narver, J.C., 1994, 'Does competitive environment moderate the market orientation-performance relationship?' Journal of Marketing 58, 46-55. https:// doi.org/10.2307/1252250

Slater, S.E. \& Narver, J.C., 1995, 'Market orientation and the learning organization', The Journal of Marketing 59(3), 63-74. https://doi.org/10.2307/1252120

Slaughter, E.S., 2000, 'Implementation of construction innovation', Building Research and Information 28(1), 1-17. https://doi.org/10.1080/096132100369055

Spanos, Y.E. \& Lioukas, S., 2001, 'An examination into the causal logic of rent generation: Contrasting Porter's competitive strategy framework and the resource-based perspective', Strategic Management Journal 22(10), 907-934. https://doi.org/10.1002/smj.174

Staw, B.M. \& Epstein, L.S., 2000, 'What bandwagons bring: Effects of popular management techniques on corporate performance, reputation, and CEO pay', Administrative Science Quarterly 45(3), 523-556. https://doi.org/10.2307/ 2667108 
Tay, L. \& Morgan, N.A., 2002, 'Antecedents and consequences of market orientation in chartered surveying firms', Construction Management and Economics 20(4), 331-341. https://doi.org/10.1080/01446190210123826

Tsiotsou, R., 2010, 'Delineating the effect of market orientation on services performance: A component-wise approach', The Service Industries Journal 30(3), 375-403. https://doi.org/10.1080/02642060802236103

Turk, Z., 2016, 'Responsible research and innovation in construction', Procedia Engineering 164(1), 461-466. https://doi.org/10.1016/j.proeng.2016.11.645

Walker, R.M., Damanpour, F. \& Devece, C.A., 2010, 'Management innovation and organizational performance: The mediating effect of performance management' Journal of Public Administration Research and Theory 21(2), 367-387. https://doi org/10.1093/jopart/muq043

Weerawardena, J., 2003, 'Exploring the role of market learning capability in competitive strategy', European Journal of Marketing 37(3/4), 407-429. https:// doi.org/10.1108/03090560310459023
Weerawardena, J., O'Cass, A. \& Julian, C., 2006, 'Does industry matter? Examining the role of industry structure and organizational learning in innovation and brand performance', Journal of Business Research 59(1), 37-45. https://doi.org/10. 1016/j.jbusres.2005.02.004

Xue, X., Zhang, X., Wang, L., Skitmore, M. \& Wang, Q., 2018, 'Analyzing collaborative relationships among industrialized construction technology innovation organizations: A combined SNA and SEM approach', Journal of Cleaner Production 173(1), 265-277. https://doi.org/10.1016/j.jclepro.2017.01.009

Zhang, J. \& Duan, Y., 2010, 'The impact of different types of market orientation on product innovation performance', Management Decision 48(6), 849-867. https:// doi.org/10.1108/00251741011053433

Zubizarreta, M., Cuadrado, J., Iradi, J., García, H. \& Orbe, A., 2017, 'Innovation evaluation model for macro-construction sector companies: A study in Spain', Evaluation and Program Planning 61(1), 22-37. https://doi.org/10.1016/j. evalprogplan.2016.10.014 